\title{
Violence against Women and Reactions to Gender Equality in Politics
}

Flávia Biroli, University of Brasilia

doi:10.1017/S1743923X18000600

Violence against women is considered a systemic social practice. Aware of the presence of systemic violence "at the horizon of social imagination," members of some groups, women in this case, learn that they might suffer it any time "simply because they are members of that group" (Young 1990, 62). This understanding encompasses physical attacks as well as humiliation, harassment, intimidation, and stigmatization. Systemic violence targets women because they are women, although they are differently affected and have gendered experiences that are also shaped by race, class, sexuality, generation, and nationality (Collins 2015).

Violence against women in politics is grounded in sexist values, practices, and institutions. Constituting a reaction to women in politics, it targets women participating in electoral contests and formal representative bodies as well as women activists. Its dynamics aim at women's bodies as much as their voices and public identities - in other words, their physical, moral, and material conditions for being politicians and engaging in public action.

Violence against women in politics can be conceptualized as a "strategy to keep positions of power" (Albaine 2015, 151) as much as an expression of "male privilege and power in society" (Restrepo Sanín 2016, 5). A phenomenon affecting women in politics worldwide (Krook 2017), it seeks to limit women's political participation and their role as legitimate interlocutors. Its implications for democratic representation and gender justice are thus undeniable.

\section{ADVANCES IN LATIN AMERICA}

In Latin America, violence against women in politics has been the subject of political debate and new legislation in recent years. In 2012, Bolivia was the first country to specifically address political violence against women in its laws. ${ }^{1}$ Mexico typified "political violence" against women in 2013, including it in a broader law preventing violence against women as well

1. “Ley contra el acoso y violencia política hacia las mujeres," Law 243, 2012. 
as in the country's electoral code. ${ }^{2}$ In other countries, recent initiatives have sought to enlarge the definition of gender violence, expanding it to include violence in politics, as in Peru, ${ }^{3}$ or connecting acts of violence against specific women to the denial of voice and rights to women in general, as in Argentina. ${ }^{4}$

These new laws and bills make a clear statement that violence encompasses stereotypes and structures reproducing gender domination. They recognize multiple dimensions of violence against women in politics (although politics is not the main issue for some of them), including physical, sexual, and psychological violence, as well as symbolic and economic violence (Krook and Restrepo Sanín 2016). Such an understanding is important, given that these different dimensions "frequently overlap and escalate" as part of an intertwined phenomenon (Restrepo Sanín 2016, 27).

\section{THE CASE OF BRAZIL}

In Brazil, recent laws against domestic violence (Law 11.340/2016) and assassination of women (Law 13.104/2015) assume a gender perspective, setting new legal parameters for prevention and criminalization. They are the result of decades of activism by feminist movements as well as transnational agreements and policies in favor of women's rights (Bandeira and Almeida 2015). Acts of political violence against women in politics have been reported by women in Congress and discussed by feminist movements, but these dynamics have not been the focus of academic research or typified yet in legal instruments. Women who have reported harassment and other aggressions, or started a lawsuit against male politicians who have menaced and humiliated them in Congress, therefore risk high exposure in a disadvantageous political environment. ${ }^{5}$

Brazil has one of the worst rates for women's formal representation in the Americas. While the regional average stands at $28.5 \%$ for women in single

2. "Ley General de Acceso de las Mujeres a una Vida Libre de Violencia" and "Código Federal de Instituciones y Procedimientos Electorales," approved by the Mexican Senate in 2013. See Cerva Cerna (2014).

3. "Plan Nacional contra la Violencia de Género," Decree n. 8/2016, and "Proyecto de Ley para Prevenir, Sancionar y Erradicar el Acoso Político contra las Mujeres," Bill 673/2016.

4. "Ley de Proteccion Integral a las Mujeres," Law 26485, 2009.

5. See Jandira Feghali, "Uma violência contra as mulheres," April 5, 2016, http://agoraequesaoelas. blogfolha.uol.com.br/2016/05/04/uma-violencia-politica-contra-as-mulheres/ (accessed April 2017); and "Juíza condena Bolsonaro por ofensas contra deputada Maria do Rosário," http://congressoemfoco.uol. com.br/noticias/bolsonaro-e-condenado-por-declaracao-ofensiva-a-maria-do-rosario/ (accessed April 2017). 
and lower houses of parliament (Inter-Parliamentary Union 2018), women constitute less than $10 \%$ of Brazilian deputies. The picture is not much better in other levels or branches of government. At the same time, however, changes in women's relative position, the agenda of organized movements acting within the state, and a growing presence of feminism in Brazilian society have placed gender-based agendas in the center of political dispute (Biroli 2016b). A woman was also elected president for the first time in 2010 and reelected in 2014.

In this mixed context, multiple negative reactions to women's participation in politics have occurred, precipitated by growing participation of women within the state structure, which started in the 1980s but accelerated after the arrival of the Workers' Party in the federal government in 2003 (Abers and Tatagiba 2015; Biroli 2018; Machado 2016; Matos and Paradis 2014). These patterns suggest that violence against women in politics as a concept should be expanded further, encompassing not only hostility to politically active women but also efforts to roll back feminist policy initiatives. These dynamics are deeply interrelated, sharing the same goal of undermining gender equality advances in the public sphere.

Since 2015 , organized attacks against a "gender perspective" and a socalled gender ideology in laws, public policies, and education have occurred in the Brazilian Congress, as well as in local politics. Critics of gender equality frame feminists as enemies and seek to reaffirm the traditional family and women's conventional roles. ${ }^{6}$ Men in Congress, for example, have spoken about feminist advances in public policy as threats "against the family" while also confronting their female colleagues who speak out and work in favor of women's rights. They accuse them of being deviant and out of touch with "real women," who, according to Federal Deputy Flavinho, are "battling to survive, do not want to be empowered, they want to be loved, they want to be cared for, they want to be respected. Feminists are the ones who want to be empowered" (Department of Tachygraphy, April 27, 2016, 83).

Laws suppressing a "gender perspective" from documents and public policy promote a view of gender inequality in society and politics as the natural state of affairs. They are thus intimately connected to a backlash against women in the political sphere. Evidence of this link can be seen in the fact that legislative proposals against "gender ideology" were

6. Legislative proposals in the Brazilian Congress to exclude "gender ideology" from current laws and educational content and/or the criminalization of ones "promoting the gender agenda" include PL 477/ 2015, RIC 565/2015, PL 1859/2015, PL 3235/2015, and PL 3236/2015. 
presented in Congress at the same time that the campaign to impeach and depose President Dilma Rousseff was occurring in 2016. The impeachment process was infused with explicit misogynistic content, with Rousseff repeatedly characterized as politically incompetent, incapable of negotiating, and neurotic (Biroli 2016a). Once she was removed from office, the new government announced a cabinet composed only of white men and cut off dialogue with women's movements. This suggests a reversal, a revival of the "most extreme stereotypes, the ones which deny legitimacy to women's presence in the public space," which earlier studies had considered overcome (Miguel and Biroli 2011, 168).

\section{CONCLUSIONS}

Experiences in Brazil suggest a need to broaden existing definitions of violence against women in politics, expanding the focus from an emphasis on reactions to increases in the number of women in politics (Cerva Cerna 2014) to include efforts to undermine the strengthening of feminism in society and the growth of feminist activism within the state. Political actions to suppress gender equality agendas in public policy are intimately connected to violence against women in politics - and more generally in society. The goal of these efforts is to erase the historical achievements of feminist movements, collectives, and networks to promote laws and policies for gender equality. Both sets of action aim to reduce the potential of women's voices to build paths to gender equality by silencing them and deconstructing feminist policy agendas.

Flávia Biroli is Professor of Political Science at the University of Brasilia and Researcher at the National Council for Scientific and Technological Development, Brasília, Brazil: flaviabiroli@gmail.com

\section{REFERENCES}

Abers, Rebecca Naeara, and Luciana Tatagiba. 2015. "Institutional Activism: Mobilizing for Women's Health from Inside the Brazilian Bureaucracy." In Social Movement Dynamics, eds. Federico M. Rossi and Marisa Von Bülow. London: Ashgate, 73-101.

Albaine, Laura. 2015. "Paridad de género y violencia política. Los casos de Bolivia, Costa Rica y Ecuador." In Integridad y equidad electoral en América Latina. Mexico City: SOMEE, 148-71.

Bandeira, Lourdes, and Tânia M. Almeida. 2015. "Vinte Anos da Convenção de Belém do Pará e a Lei Maria da Penha." Revista Estudos Feministas 23 (2): 501-17. 
Biroli, Flávia. 2016a. “Political Violence against Women in Brazil.” Direito ๒ Práxis 7 (15): $557-89$.

. 2016b. "Sobre Lutas, Avanços e Reações: Feminismos e a Reorganização das Esquerdas." In Encruzilhadas da democracia, eds. Luis Felipe Miguel and Flávia Biroli. Porto Alegre: Editora Zouk, 91-117.

- 2018. Gênero e desigualdades: limites da democracia no Brasil. São Paulo: Boitempo Editorial.

Cerva Cerna, Daniela. 2014. "Participación Política y Violencia de Género en México." Revista Mexicana de Ciencias Políticas y Sociales 59 (222): 105-24.

Collins, Patricia Hill. 2015. "Intersectionality's Definitional Dilemmas." Annual Review of Sociology 41: 1-20.

Inter-Parliamentary Union. 2018. "Women in National Parliaments: Situation as of 1 January 2018." http://archive.ipu.org/wmn-e/arc/world010118.htm (accessed March 7, 2018).

Krook, Mona Lena. 2017. "Violence against Women in Politics." Journal of Democracy 28 (1): 74-88.

Krook, Mona Lena, and Juliana Restrepo Sanín. 2016. "Gender and Political Violence in Latin America.” Política y Gobierno 23 (1): 125-57.

Machado, Lia Zanotta. 2016. "Brazilian Feminists in their Relations with the State: Contexts and Uncertainties." Cadernos Pagu 47: 1-37.

Matos, Marlise, and Clarisse Goulart Paradis. 2014. "Desafios à Despatriarcalização do Estado Brasileiro." Cadernos Pagu 43: 57-118.

Miguel, Luis Felipe, and Flávia Biroli. 2011. Caleidoscópio Convexo: Mulheres, Política e Mídia. São Paulo: Editora da Unesp.

Restrepo Sanín, Juliana. 2016. "Violence against Women in Politics and the Law." Presented at the 24th World Congress of the International Political Science Association, Poznan, Poland, July.

Young, Iris Marion. 1990. Justice and the Politics of Difference. Princeton, NJ: Princeton University Press.

\section{Intersectional Violence against Women in Politics}

\section{Rebecca Kuperberg, Rutgers University}

doi:10.1017/S1743923X18000612

The field of violence against women in politics (VAWIP) is so new, it seems unfair to discuss its "gaps"; rather, the study of VAWIP is defined by its uncharted territory. The bulk of existing literature, compiled by scholars as well as practitioners, emphasizes theoretical conceptualization, empirical forms of violence, and the tracking of incidents across regions (Krook 2017; Krook and Restrepo Sanín 2016). Researchers have stressed the gendered motivations and implications of VAWIP. In short, women 